\title{
Sustainability Initiatives Driving Supply Chain: Climate Governance on Beef Production System
}

\author{
leda Kanashiro Makiya', Clyde William Fraisse²
}

\begin{abstract}
Two conceptual frameworks have been analytically dominant in researching innovation dynamics in sustainability transition processes, namely Technological Innovation Systems (TIS) and the Multi-Level Perspective (MLP). The innovation systems has been principally concerned with emerging new technologies and their potential contribution to future sustainability, whereas MLP has been more strongly oriented toward reconstructing historical processes of sectorial change.

In this perspective, this study aims to analyses how global climate change and environmental pressures impact on the governance of supply chain and the ripple effects on natural resource-intensive economies. Initiatives are taken to address regulatory issues and reconcile decision-making tools on quality assurance program on value chains. This includes a MultiLevel Perspective (MLP) as Carbon Disclosure Project (CDP) and Technological Innovation Systems (TIS) as Geographic Information System (GIS) used as a tracking system for monitoring sustainable practices.

The paper discusses the drivers of sustainable beef production system, mainly in Legal Amazon, Brazil, and requirements from a largest retailer aligned to Brazilian Public Policies. This part presents three distinct strategies: (I) government and public policies to control deforestation related to beef cattle production system, (2) economic approach related to transnational supermarket chain and sustainability initiatives, (3) collective action for decision-making by multiple drivers
\end{abstract}

Keywords: Sustainability, Multi-Level Perspective, Technological Innovation System.

'School of Applied Sciences, State University of Campinas, UNICAMP, R. Pedro Zaccaria, I 300, zip code I 3484-350, Limeira, São Paulo, Brazil. E-mail: eda.makiya@fca.unicamp.br (corresponding author).

${ }^{2}$ Agricultural and Biological Engineering, University of Florida, 239 Frazier Rogers Hall , PO Box I I 0570 Gainesville, FL 326 I I . 


\section{Introduction}

The globalization process impacts on gradual changes related to the competitive environment. Initially the dilution of geographical boundaries conditioned to a decrease of competition between countries forward to an empowerment of decision-making of large companies on market behavior. After this process, nowadays we realize that the competition changed into another level focused on supply chain as top decision on defining rules up and downstream.

This model also called buyer-driven value chain (Gereffi and Memedovic, 2003) or "manufacturers without factories" are those in which large retailers, marketers and branded manufacturers play the pivotal roles in setting up decentralized production networks in a variety of exporting countries, with considerable control over how, when and where manufacturing will take place, and how much profit accrues at each stage.

It becomes fundamental to understand how entrepreneurship and innovation for sustainability in Natural Resourse-Intensive Economies (NRIEs) must integrate hopefully agenda for discussion about alternatives for sustainable development of local production systems. As the world economy rebounds, according to Deloitte (2013) agriculture investments in developing countries-led by the rising markets of China, India, and Brazil-will likely increase significantly, coupled with billions of dollars targeted by multilateral donors to support food security programs in developing nations, global agriculture may experience a second green revolution-one driven by a truly global market demand.

Indeed, global product markets are undergoing profound changes on demand conditions, structure and modus operandi of supply relations, as well as private and public modes of supply chain governance, as pointed by Masakure et al (2009). In this context to be successful in international markets requires upgrading and transformation by developing country exporters. At the same time the shift to a Bioeconomy by Harvey \& Pilgrim (20II) and sustainable agriculture for food and energy is likely to re-shape the geopolitical environment of the world. Flows of food and energy/materials will be re-drawn, and different regions will pursue different innovation pathways as a consequence of their diverse political objectives and natural endowments.

By the way, the public authority delegates social and environmental regulation to the private sector based on 'voluntary' standards and certifications on sustainability. But they are mandatory for producers and other value chain actors if they want to supply the large processors and retailers (such as Unilever and Wal-Mart) that are increasingly demanding certified 'sustainable' products. In the agro-food and forestry sectors, many initiatives have taken the form of 'stewardship councils' and 'sustainability roundtables (Ponte, 2014) that explicitly signal their multistakeholder nature in their titles.

Two conceptual frameworks have been analytically dominant in researching innovation dynamics in sustainability transition processes, namely Technological Innovation Systems (TIS) and the Multi-Level Perspective (MLP) (Coenen et al, 20I2). Both approaches conceptualize socio-technical systems as semi coherently interrelated sets of actors, networks institutions and technologies/artifacts. The innovation systems applied to sustainability has been concerned with emerging technologies and their potential contribution, whereas MLP has been more strongly oriented toward reconstructing historical processes of sectorial change.

In this perspective, this study aims to analyses how global climate change and environmental pressures impact on the governance of supply chain and the ripple effects on natural resource-intensive economies. Some initiatives are taken to address regulatory issues and reconcile decisionmaking tools on quality assurance program on value chains. This includes a multi-level perspective (MLP) as Carbon Disclosure Project (CDP) and Technological Innovation Systems (TIS) as Geographic Information System (GIS) used as a tracking system for monitoring sustainable practices.

The paper is structured into three parts. The first part (Section 2) outlines a theoretical framework of global climate change and environmental requirements on sustainability transition, and robust policy solutions and their effective, equitable implementation. The buyer-driven value chain related to Transnational Supermarket Chains (TSCs). The second part (Sections 3) reviews the drivers of sustainable beef production system, mainly in Legal Amazon, Brazil, and requirements from a largest retailer aligned to Brazilian public policies. This part presents three distinct strategies: government and public policies to control deforestation related to beef cattle production system, economic approach related to transnational supermarket chain and sustainability initiatives, collective action for decision-making by multiple drivers. In the final part (Section 4), we present some final remarks.

\section{Theoretical framework}

Climate change calls for new approaches to sustainable development that take into account complex interactions between climate and social and ecological systems, that combine adaptation and mitigation, continually evolving processes for managing change. One way that sustainable development pathways (IPCC, 20I4) can contribute to climate resilience is by pursuing consumption patterns that 
assure social and economic development while reducing use of natural resources and maintaining ecosystem services. It is possible that the desired objectives of consumption might be met in ways that require fewer resources and produce fewer emissions.

Building bridges and improving the "traditional" core of sustainability transition studies, Markard et al (20I2) include: economic geography, with its focus on the spatial and institutional contexts of innovation; philosophy of science, concerned with the ontological basics of theoretical frameworks; management studies, which pay attention to the role of organizational strategies and capabilities; sociology, which highlights that transition contexts do not exist per se, but are constantly reconstructed by the broad variety of actors involved; modeling, concerned with the development of computational models to simulate transitions; policy studies, which point to the role of power struggles; and policy advice, which has to transform itself to accept a broader range of rationales for intervention.

Besides this, sustainable entrepreneurship hence embodies a new form of entrepreneurial value creation aimed at fostering four central factors: social justice, environmental protection, economic prosperity and intra and intergenerational equity. It is a mechanism for sustaining nature and ecosystems while providing economic and non-economic gains for investors, entrepreneurs and societies. (Muñoz, 2013)

Some corporate strategies assume the organizational and informational infrastructure for assessing, measuring, reporting and managing GHG emissions and their associated impacts. As emissions trading emerges as the primary policy response to the threat of climate change, business has intensified its development of GHG accounting and management capabilities in order to establish baselines, measure actual emissions and budget for the future purchase (or sale) of emission credits. Simultaneously, business is under increasing pressure from investors and environmental non-governmental organizations (NGOs) to disclose information related to their GHG emissions. NGOs are actively mobilizing large institutional investors in this respect with the argument that carbon disclosure represents information that is crucial for the more accurate valuation of assets. In turn, the information can also be used by NGOs to pressure firms to change their practices. (O'Dwyer et al., 2005). (Kolk et al, 2008)

This trajectory lead to an integrated global change research for providing a better understanding of the multiple drivers, interdependencies and complexities of global sustainability challenges to the development of robust policy solutions and their effective, equitable implementation. It is the basis of high-impact international science-policy assessments, cited by Mauser et al (20/3), such as the 'Millennium Ecosystem Assessment', the 'Intergovernmental Panel on Climate Change', 'The Economics of Ecosystems and Biodiversity' and the recently established 'Intergovernmental Platform on Biodiversity and Ecosystem Services'.

All these commitments increase the ability to make informed judgments and to take effective decisions regarding the use and management of carbon, through both individual behavior change and collective action. Three core dimensions of carbon capability are identified by Petri et al (2014): (a) decision-making (knowledge, skills, motivations and judgments), (b) individual behavior or 'practices' (e.g. energy conservation), and (c) broader engagement with systems of provision and governance (e.g. lobbying, voting, protesting, creating alternative social infra- structures of provision).

In addition, international organisms, the evolution of environmental control methods, the internationalization of activities and the universalization of labor rights and the sustainable development ideal have started to stablish minimum rules or parameters (Maffini Gomes et al, 20l3) so that a company can operate in a given activity or region.

\section{Sustainable Beef in Legal Amazon}

Brazil has the second largest commercial cattle herd in the world; it is the second largest beef exporter, second largest meat producer and the sixth largest producer of milk (USDA, 2014). In 2013 the Gross Value of Production (GVP) of beef was $R \$ 5 \mathrm{I}$.I billion, behind only the soybean complex (Brazil, 2014). The beef production chain moves $R \$$ 167.5 billion per year, generating about 7 million jobs (Neves, 2012). In 2013 the country produced 9.6 million tons of beef, of which about 7.6 million tons were for the domestic market (CONAB, 20I4).

Brazil's non-Amazon cattle herd slightly declined from 19942009, but more than doubled in the Legal Amazon., and 37\% of all Brazilian cattle were located in the Legal Amazon by 2009. The exporting slaughterhouses are owned by a handful of meatpackers, over two-thirds of which have signed up to the Greenpeace Cattle Agreement (Walker et al, 2013)

Environmental issues are a primary and growing concern in Brazil, and numerous interventions are being developed to tackle deforestation directly and indirectly through the cattle supply chain.

In this way, the use and access to increasingly scarce natural resources have been controlled primarily by three distinct strategies (Ferreira, 2010): one in which the Government is the primary regulator, justified in the sense that has legitimate authority and capacity to mediate conflicts in environmental 
behalf of the community; economic approach, in which the very market forces are used to drive the environmental actions of economic agents; and a strategy based on collective action, namely, the management of natural resources by the users, through formal or informal institutions. However, pressures on the environment continue to grow and these strategies, while having vital role, each have a number of limitations, making clear that their effectiveness depends, increasingly, the cooperative interactions between them.

\section{I Government as the primary regulator}

The reduction of Amazonian deforestation rates in Brazil has thus occurred largely under innovative polycentric governance (Chow et al, 2013) -international, federal, and local-and among wide ranging interest groups, e.g., international NGOs, Brazilian civil society, indigenous groups, commodity producers, and state and federal governments.

Since 2005, with relatively little notice worldwide, a dramatic transformation has occurred in the Brazilian Amazon. The soybean and beef cattle industries continue to expand economically, but far less at the expense of the rainforest. Effective protection has been extended to indigenous reserves and other protected areas. (Boucher et al, 20l3)
These commitments aimed at reducing greenhouse gas emissions were incentivized by pledges of up to $\$$ I billion from the Norwegian Climate and Forest Initiative (Chow et al, 20/3) to the Brazilian Amazon Fund, which was implemented via multilateral funding platforms and is contingent upon verified progress in reducing deforestation. Other important factor is the Ecological-economic zoning (ZEE) (Arima et al, 2005) as a pre-condition for international investments (for example, theWorld Bank) and it can reduce uncertainty - mainly because it allows regulatory Recovery of Legal Reserve in private properties in accordance with the current Forest Code.

In accordance with these multiple factors, the Rural Environmental Registry (CAR - Cadastro Ambiental Rural) is a pivotal key to assist the process of environmental regularization of rural properties and possessions instrument. Consists of a survey of geo-referenced information of the property, with delineation of Permanent Protection Areas (APP - Área de Proteção Permanente), Legal Reserve (RL Reserva Legal), remnants of native vegetation, consolidated rural area, areas of interest and social utility, with the aim of drawing a digital map from which the values of the areas are calculated for environmental assessment. Important to assist in the planning of rural property and reclamation tool, CAR promotes the formation of ecological corridors and the conservation of other natural resources, contributing to the improvement of environmental quality, currently being used by state and federal governments. (Brazil, 20l4b).

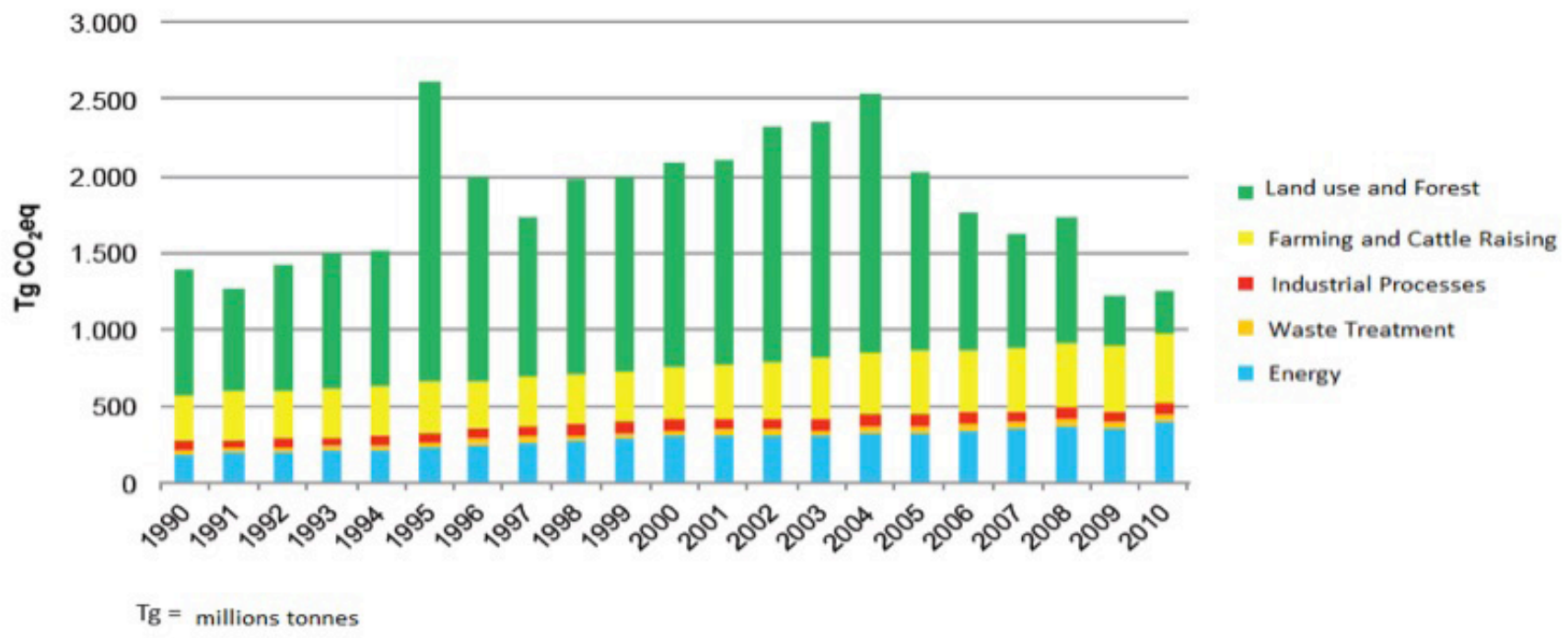

Figure I - Brazilian greenhouse gases emissions, I999-20I0 period. (Brasil, 20I3)

ISSN: 07 I8-2724. (http://www.jotmi.org) 
In 2009 the Public Prosecutors imposed a Conduct Adjustment Term (TAC - Termo de Ajuste de Conduta) on slaughterhouses and retailers, forcing these actors to buy cattle only from properties with the CAR. Consequently, no cattle from illegally deforested properties (such as those in IBAMA-embargoed areas) can be sold. Fines are levied against actors who do not comply with the TAC. This moratorium resulted in slaughterhouses and retailers exerting pressure over producers to avoid illegal deforestation and to become compliant with the Forest Code, and changed the criteria used by slaughterhouses to select their suppliers. The threat of losing income is a significant incentive to producers to change their practices and to stop deforestation. (Drigo 2013) (Alves-Pinto et al, 20l3).

Since this, the Federal Public Ministry (MPF) of Para filed lawsuits against slaughterhouses that bought meat from embargoed areas. As a result, three large slaughterhouses signed a Conduct Adjustment (TAC) pledging, among other obligations, to buy cattle only from suppliers whose areas were inserted in Rural Environmental Registry (CAR), administered by the Ministry of Environment of Pará (Sema) (Barreto and Silva, 2009).

\subsection{Economic approach}

Transnational agrifood firms systemically integrate small growers in developing countries into global sourcing networks with expansive supply chains (Lee et al, 2012) increasing their flexibility to source high-volume, low-price, diversified agrifood regulation systems. Their enormous buying power and well-known consumer brands allow them to dictate cost-cutting measures and enhanced standards to their suppliers.

Depending on the degree of concentration in food production (farmers and manufacturers) and in food retail (supermarkets and other food retailers), four different value chains governance (Figure I) (Lee et al, 20I2) play a central question surrounding how to strike a balance between economic, social, and environmental well-being at both ends of the farm-to-fork chain: farmers and consumers.

Transnational supermarket chains (TSCs), the most powerful actors in the global agro-food system, are increasingly using such attributes as quality, safety, labor, and the environment to differentiate the marketplace for food. Particularly the leading TSCs of Wal-Mart, Carrefour, Kroger, Metro AG, Ahold, Albertson's, Safeway, and Sainbury's (Konefal et al, 2005) are also using standards to develop new niche markets, such as organic, fair trade, free range, and goods that are locally produced. In these ways, standards not only define product attributes, but also production practices, handling requirements, and distribution.

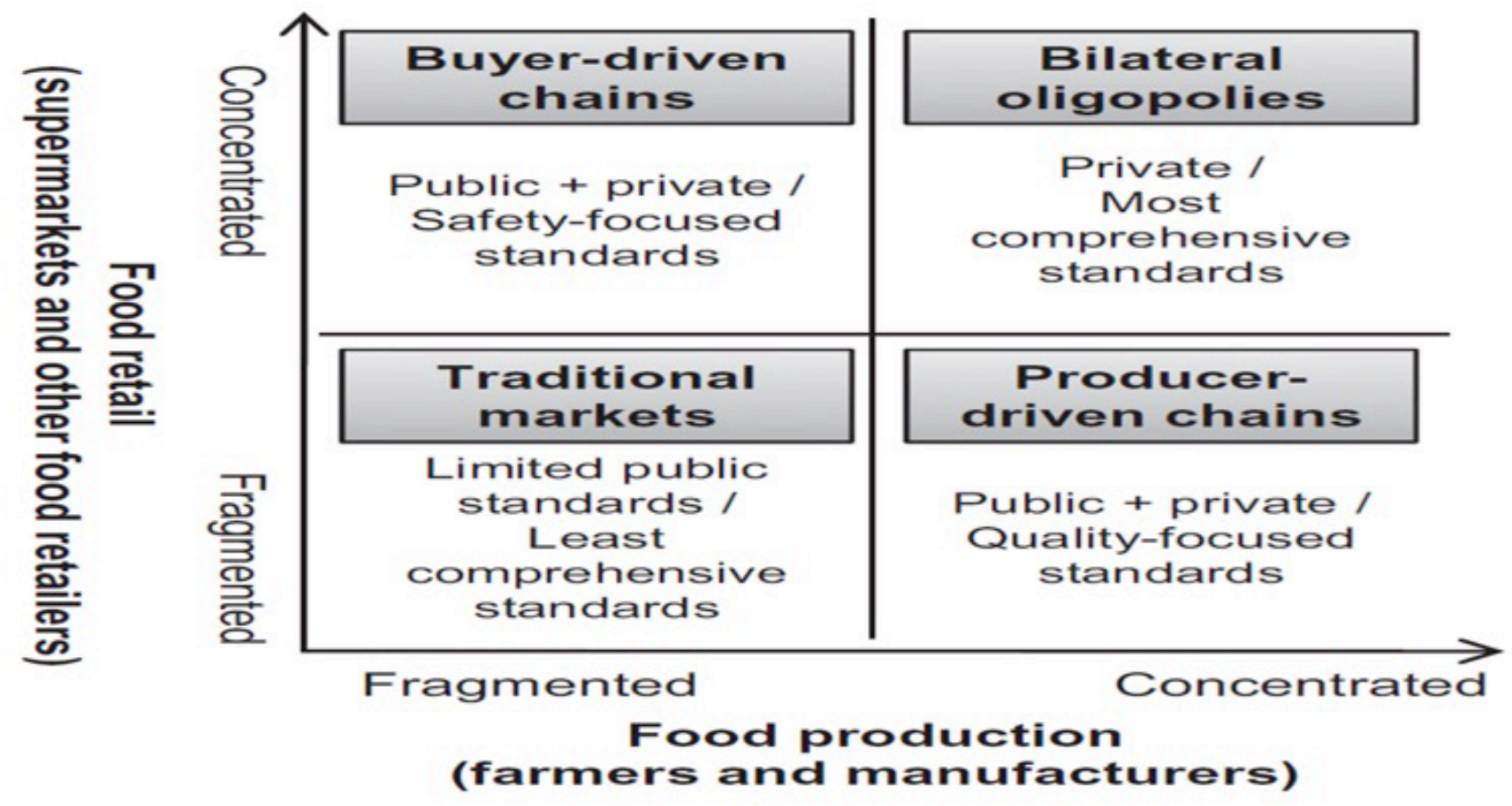

Figure 2 - Global Value Chain structure and agrifood standards. Data based on Lee et al (20I2)

ISSN: 07 I 8-2724. (http://www.jotmi.org)

Journal of Technology Management \& Innovation @ Universidad Alberto Hurtado, Facultad de Economía y Negocios. 
In general, relations in the supply chain provide opportunities to improve competitiveness that can also be extended geographically through information and communication technologies (Macpherson, Jones \& Zhang, 2005) and supply chain management (SCM) practices tend to influence positively the innovation of products and process (Didonet \& Diaz, 2012). Also innovation process showed differences based on network configuration: in the vertical network (innovation by top-down decision) and in horizontal network (innovation by bottom-up decision) (Alves et al, 20I I)

Then, aligning the public policy as TAC and CAR to transnational supermarket chains, it is possible to observe (Figure 3) the integration of activities related to technological innovation systems (TIS) as Geographic Information System (GIS) used as a tracking system for monitoring sustainable practices.

Geographic Information Systems (GIS) synthesize a wide variety of data and analyze complex spatial relationship grounded in physical locations of key Natural ResourceIntensive Economies (NRIEs), and it's becoming fundamental for planning and decision-making. This support measurement of social and environmental impacts in non-regulated markets as Walmart.. The combination of traditionally top-down GIS and bottom and bottom-up participatory mapping methods provides a vital link between designing and information effective large-scale development plans to coordinating and implementing locally-relevant sustainable solutions.

The current situation of rural and urban registries in Brazil shows that many challenges remain to be overcome. Existing data are still based on 2D dispersed in different institutions under different standards. Despite these difficulties, some opportunities to reverse situation can be related to the geo-referencing CNIR, the Act No. 6666/2008, which established the implementation of the National Spatial Data Infrastructure - NSDI, are pioneering standards that indicate the real possibility of implementing a registration territorial multitask built in Brazil through institutional partnerships. For the success of a multipurpose 3D land survey, there is an urgent need to define the standards for structuring and exchanging data, since much has been lost by the lack of accurate information about the Brazilian territory. (Carneiro et al, 2012)

Projects share common associations with spatial data and the need for effective stakeholder participation in planning process. (Vajjhala, 2005)

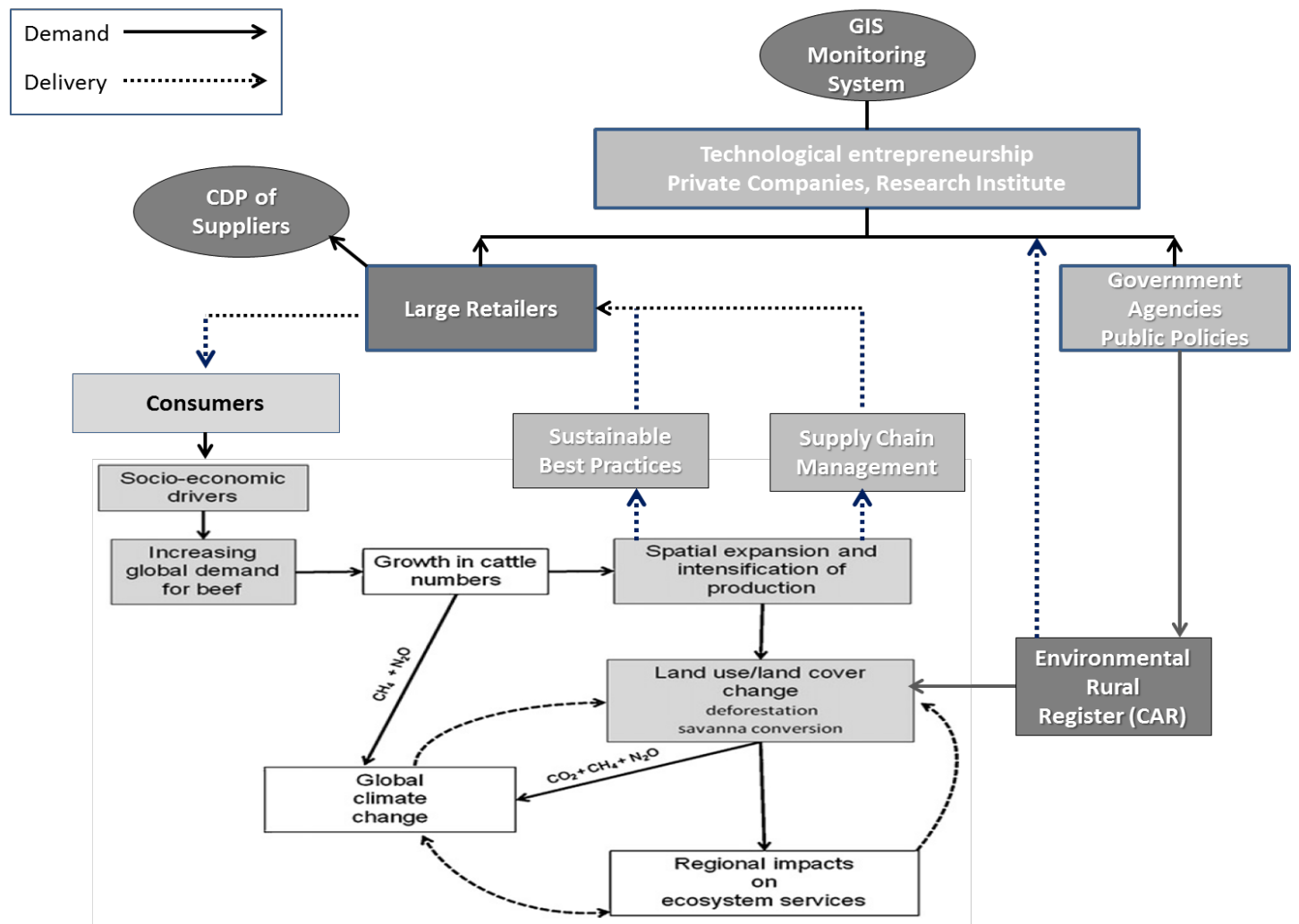

Figure 3 - Conceptual model of the socio-economic drivers of increased global demand for beef and resulting impacts and feedbacks on the regional and global environmental. Data based on McAlpine et al (2009) adapted by authors

ISSN: 07 I8-2724. (http://www.jotmi.org)

Journal of Technology Management \& Innovation @ Universidad Alberto Hurtado, Facultad de Economía y Negocios. 
Leading companies, according to Deloitte (2013) are investing in securing their supply chain, developing plans to manage recalls, and enhancing product labeling and traceability in compliance with all regulatory regimes where their product is consumed. Systems are also improving supply chain transparency through track and trace technologies to enhance communication and to ensure all members of the chain understand the risks associated with a safety failure.

One of these initiatives is Carbon Disclosure Project, multilevel perspective (MLP), an international, not-for-profit organisation providing a global system for companies and cities to measure, disclose, manage and share vital information. It has a diverse funding base which includes companies, investors, governments and philanthropic sources; it works with 767 institutional investors holding US\$92 trillion in assets to help reveal the risk in their investment portfolios. Programs are being used in $8 \mathrm{I}$ countries around the world. CDP is headquartered in London, UK, and has offices in New York, Berlim, Brussels, Sydney, Stockholm, Milan, Sao Paulo, New Delhi, Beijing and Tokyo (CDP, 20I4).

The advocacy of voluntary corporate carbon disclosure represents a form of institutional entrepreneurship geared toward leveraging carbon disclosure as a form of governance. The institutionalization of carbon disclosure is a political project $(K o l k, 2008)$ because it entails a change in the structures of corporate governance in a way that shifts attention toward environmental objectives and enhances the legitimacy and engagement of environmental NGOs in governance processes.

In 2012, Walmart requested climate change disclosures from 3,000 of its largest suppliers by spend through CDP's platform. Of the I, 100 suppliers who submitted responses, 58 percent of them reported more than 2,400 greenhouse gas emission reduction activities through CDP. Of these initiatives, 640 (27 percent) will pay back within the year and I,247 (52 percent) will have a payback period of three years or less. Together, CDP and Walmart are working with suppliers of all types of products - from toothpaste to lawn mowers to video games - to measure, manage, reduce and report their impact on climate change. (Walmart, 20I3)

The three largest slaughterhouses in Brazil - Marfrig, JBS, and Minerva - process a major proportion of the total cattle. In the state of Mato Grosso a single slaughterhouse JBS - is responsible for almost $50 \%$ of all the beef processed (IMEA 20II) and the largest beef retailer groups in Brazil are Grupo Pão de Açucar, Carrefour, and Wal-Mart (ABRAS 2013) (Alves-Pinto et al, 20l3). As consequence all of them are commitment with climate governance.

\subsection{Collective Action}

In 2010, the Sustainable Agriculture Network (SAN) consortium launched a standard for environmental and social responsibility in cattle production (SAN 2010). A combination of government, civil society, and private sector initiatives will likely continue to improve the chain in the near future, with significant potential for further reductions in deforestation and greenhouse gas emissions associated with cattle ranching. (Alves-Pinto et al, 2013).

Socio-environmental agricultural certification is a marketing tool created in the context of the increasing importance of environmental and social standards by informing consumers that the product they buy comes from socially and environmentally responsible sources. The Sustainable Agriculture Network (SAN) adopted the RAC (Rainforest Alliance Certified) label to identify products and certified operations based on its Sustainable Agriculture Standards, which are the result of internal discussions, public consultations and a review of similar standards. Since 1992, more than 700 certificates for more than 130,000 farms - including small family farms of cooperatives, as well as plantations - in 29 countries (Argentina, Brazil, Chile, Colombia, Costa Rica, Côte d'Ivoire, Dominican Republic, Ecuador, El Salvador, Ethiopia, Ghana, Guatemala, Honduras, India, Indonesia, Jamaica, Kenya, Malawi, Mexico, Nicaragua, Panama, Papua New Guinea, Peru, Philippines, Sri Lanka, Tanzania, United States, Vietnam and Zambia) have met the Sustainable Agriculture Standard. (SAN, 20I4)

Other entrepreneur initiatives (Earles \& Williams, 2005) for adding value through on-farm processing: Holistic Management, Evaluating a Rural Enterprise, Moving Beyond Conventional Cash, Cropping, Entertainment Farming and Agri-Tourism, Agricultural Business Planning Templates, Enterprise Budgets and Production Costs for Organic Production, Preparing for an Organic Inspection: Steps and Checklists, Direct Marketing, Farmers' Markets, CSA (Community Supported Agriculture), Bringing Local Food to Local Institutions, Selling to Restaurants, Organic Certification and the National Organic Program, Organic Marketing Resources, Alternative Meat Marketing

The effective introduction of Brazilian beef, cited by Euclides Filho (2004), into the world economy and increased beef consumption by the internal market will depend on the ability of production systems and other sectors of the beef supply chain to provide healthy products, to utilize non-renewable sources in a sustainable manner, to assure people's welfare, to increase its share of the internal market, and to contribute to better social equity. 


\section{Final Remarks}

Beef production in Brazil has been growing in the Legal Amazon region, and producers will have to adapt to the new rules of production under the scope of sustainability as defined by large retailers. The consumer market is global and the agro industrial sectors have been monitored closely, according to international standards for supply chain management in order to increase transparency and sustainability in the whole system. Many tools have been implemented to ensure good manufacturing practices, traceability in the supply chain, monitoring of environmental, economic and social indicators, as requirements used for trade barriers in commercialization of these products in global markets. Questions focused on sustainability, mainly related to the Legal Amazon have been developed by the public, private and non-governmental organizations scope in joint actions to assist Brazilian beef cattle production comply with the new rising parameters.

Through an exploration of the macro forces shaping the agro-food system and the micro-politics of social activism by collective actions, we realize a shifting from government to governance, and in particular approach for sustainable movements. In this context, integration practices and discourse have the potential to reproduce the effectiveness of a Multi-Level Perspectives as Carbon Disclosure Project and Technological Innovation Systems (TIS) as Geographic Information System (GIS) as important skill for aligned Conduct Adjustment Term (TAC - Termo de Ajuste de Conduta) and Rural Environmental Registry (CAR Cadastro Ambiental Rural) monitoring tools, whose support public policies to Transnational Supermarket Chains (TSC) activities for effectiveness of sustainable practices.

\section{Acknowledgments}

The authors acknowledge the support of this research by School of Applied Sciences, State University of Campinas (FCA-UNICAMP-Brazil), Project 2455-13-7, Coordination Body for Improvement of Graduated Students, (Projeto 2455-13-7, CAPES-Brazil), Climate Variability and Change Laboratory, Agricultural and Biological Engineering, University of Florida (ABE-UF), agroclimate.org.

\section{References}

ALVES, R., Figueira, M., Castro, C., Sugano, J., \& Soares, A. (20I3). Innovation Processes in Small and Medium Enterprises Associated in Networks from the Supermarket Sector. Journal Of Technology Management \& Innovation, 8, 6I-7I. doi:http://dx.doi.org/|0.4067/S07 | 8-272420|300030006|

ALVES-PINTO H, Newton P, Pinto L. (20/3). Certifying sustainability: opportunities and challenges for the cattle supply chain in Brazil. CCAFS Working Paper no. 57. CGIAR Research Program on Climate Change,Agriculture and Food Security (CCAFS). Copenhagen, Denmark. Available online at: www.ccafs.cgiar.org

ARIMA, E., Barreto, P.; Brito, M. (2005). Pecuária na Amazônia: tendências e implicações para a conservação ambiental. Belém: Instituto do Homem e Meio Ambiente da Amazônia.

BARRETO, P., Silva, D. (2009). Os desafios para uma pecuária mais sustentável na Amazônia. Série $O$ Estado da Amazônia 14. Belém-PA: IMAZON. Available in: http://www.imazon. org.br/publicacoes/o-estado-da-amazonia/os-desafios-parauma-pecuaria-mais-sustentavel-na

BOUCHER, D., Roquemore, S. and Fitzhugh, E. (20|3). Brazil's success in reducing deforestation. Tropical Conservation Science. Special Issue Vol. 6(3):426-445. Available online: www.tropicalconservationscience.org

BRAZIL (2014a) Ministry of Agriculture, Livestock and Supplies. Commercial Balance July 2014. Available in: http://www.agricultura.gov.br/internacional/indicadores-eestatisticas/balanca-comercial

BRAZIL (20I4b) Ministry of Environment. Rural Environmental Registry - Cadastro Ambiental Rural (CAR). Available in: http://www.mma.gov.br/desenvolvimento-rural/ cadastro-ambiental-rural.

BRITO, B., Cardoso Jr., D., Pinto, A., Adams, M. (20I I) Análise de termos de ajustamento de conduta para a recomposição de passivo ambiental de imóveis rurais no Pará. Belém, PA: IMAZON, 20II.

BROWN, S., Getz, C. (2008). Privatizing farm worker justice: regulating labor through voluntary certification and labeling. Geoforum 39 (2008) II84-1196. doi:10.1016/j. geoforum.2007.01.002 
CARNEIRO, A.F.T., Erba, D.A., Augusto, E.A.A. (20I2) Cadastro multifinalitário 3D: conceitos e perspectivas de implantação no Brasil. Revista Brasileira de Cartografia (20I2) n. 64/2: 257-27I. Sociedade Brasileira de Cartografia, Geodésia, Fotogrametria e Sensoriamento Remoto ISSN: 1808-0936

CDP (20/4) Guidance for companies reporting on climate change on behalf of investors \& supply chain members. Available in: https:/www.cdp.net/Documents/ Guidance/20I4/Climate-change-reporting-guidance-20I4. pdf

CHOW, J., Doria, G., Kramer, R., Schneider, T., and Stoike, J. 2013. Tropical forests under a changing climate and innovations in tropical forest management. Tropical Conservation Science. Special Issue Vol. 6(3):3I5-324. Available online: www.tropicalconservationscience.org

COENEN, L., Benneworth, P., Truffer, B. (2012) Toward a spatial perspective on sustainability transitions. Research Policy 4I (2012) 968-979. doi:I0.10I6/j.respol.20I2.02.0I4

DELLOITE (2013) The food value chain: a challenge for the next century. Available in: http://www.deloitte.com/ assets/Dcom-Ukraine/Local\%20Assets/Documents/ Industries/2013/FBA/Food_Value_Chain_2013.pdf

DIDONET, S., \& Díaz, G. (20I2). Supply Chain Management Practices as a Support to Innovation in SMEs. Journal Of Technology Management \& Innovation, 7(3), 91-109. doi:http://dx.doi.org/I 0.4067/S07 I8-272420 I 2000300009

EARLES, R.; Williams, P. (2005) Sustainable agriculture: an introduction. ATTRA: The National Sustainable Agriculture Information Service, NCAT: National Center for Appropriate Technology. Available in: http://www.hfcsd.org/webpages/ rlivingston/files/sustagintro.pdf

FERREIRA, I.N.R. (20I0) Parcerias para gestão ambiental em propriedades rurais: o caso de Lucas do Rio Verde - MT. Master Dissertation. University of Brasilia.

GEREFFI, G., Memedovic, O. (2003) The global apparel value chain: what prospects for upgrading by developing countries. United Nations Industrial Development Organization UNIDO,Vienna.

HARVEY, M., Pilgrim, S. (20I I) The new competition for land: Food, energy, and climate change. Food Policy 36 (201 I) S40-S5I. doi:10.1016/j.foodpol.2010.11.009
IPCC - Intergovernmental Panel on Climate Change (2014) WGII AR5 Chapter 20 - Climate Resilient Pathways: Adaptation, Mitigation, and Sustainable Development. Available in: http://ipcc-wg2.gov/AR5/images/uploads/ WGIIAR5-Chap20_FGDall.pdf

KOLK, A., Levy, D., Pinkse, J. (2008) Corporate Responses in an Emerging Climate Regime: The Institutionalization and Commensuration of Carbon Disclosure. European Accounting Review,Volume 17, Issue 4,7I 9-745, 2008. DOI: 10.1080/09638|80802489|2|

LEE, J., Gereffi, G., Beauvis, J. (20I2) Global value chains and agrifood standards: challenges and possibilities for smallholders in developing countries. Proceedings of National Academy of Sciences, PNAS, July 31, 2012, v 109, n. 3I. doi: 10.1073/pnas.09/37/4108

LIMA,A.; Keppe,A.; Palmieri, R.;Alves, M.; Maule , R., Sparovek, G. (2008) Impact of Sustainable Agriculture Network (SAN) certification on coffee farms. Institute of Management and Agricultural and Forest Certification (Imaflora). Brazil. I-53 p.(http://www.eco-index.org/search/pdfs/IMAFLORA-SAN. pdf). ISBN 978-85-9808I-I2-0

MACPHERSON, A., Jones, O., Zhang, M. (2005). Virtual reality and innovation networks: opportunity exploitation in dynamic SMEs, International Journal of Technology Management, 30(I/2), 49-66. http://dx.doi.org/10.1504/ ijtm.2005.006345

MAFFINI GOMES, C., Kruglianskas, I., Scherer, F., da Luz Neto, R., \& Marques Kneipp, J. (2013). Strategies for Sustainable Business and Performance in Brazilian Industrial Companies. Journal of Technology Management \& Innovation, 8, 25I-263. doi:http://dx.doi.org/| 0.4067/S07 | 8-272420 | 3000300023

MARKARD, J., Raven, R., Truffer, B. (2012) Sustainability transitions: An emerging field of research and its prospects. Research Policy 4I (2012) 955- $967 . \quad$ doi:10.1016/j. respol.2012.02.013

MASAKURE, O., Henson, S., Cranfield, J. (2009) Standards and export performance in developing countries: Evidence from Pakistan. The Journal of International Trade \& Economic Development Vol. 18, No. 3, September 2009, 395-419 DOI: $10.1080 / 09638190902986538$

MCALPINE, C.A., Etter A.B, Fearnside C.P.M., Seabrook L.A, Laurance,W.F. (2009) Increasing world consumption of beef as a driver of regional and global change: A call for policy action based on evidence from Queensland (Australia), Colombia and Brazil. Global Environmental Change 19 (2009) 2I-33. doi:10.1016/j.gloenvcha.2008.10.008 
MUÑOZ, P. (2013) The distinctive importance of sustainable entrepreneurship. Current Opinion in Creativity, Innovation and Entrepreneurship Volume 2, Issue I, November 2013 DOI: I0.1 I565/cuocient.v2il.26

O'DWYER, B., Unerman, J. and Hession, E. (2005) User needs in sustainability reporting: perspectives of stakeholders in Ireland, European Accounting Review, I4(4), pp. 759-787. DOI: I0.1080/09638I80500104766

PETRI, I., Beach,T., Rezgui,Y.,Wilson, I.E., Li, H. (20 I4). Engaging construction stakeholders with sustainability through a knowledge harvesting platform. Computers in Industry 65 (2014) 449-469. doi:10.1016/j.compind.2014.01.008

SAN (2014) Sustainable Agriculture Network. Who are we? Available in: http://san.ag/web/about-us/who-are-we-2/

SAN (2014) Sustainable Agriculture Network. Types of standards and policies. Available in: http://san.ag/web/ourstandard/types-of-standards-and-policies/

VAJJHALA, Shalini P. (2005). Integrating GIS and participatory mapping in community development planning. ESRI International User Conference, Sustainable Development and Humanitarian Affairs Track, Sand Diego, July 2005

WALMART (2013) CDP and Walmart: A partnership to reduce suppliers' greenhouse gas emissions. Available in: http://blog.walmart.com/cdp-and-walmart-a-partnership-toreduce-suppliers-greenhouse-gas-emissions 